Veiga, J., and F. Valera. 2020. Nest box location determines the exposure of the host to ectoparasites. Avian Conservation and Ecology 15(2):11. https://doi.org/10.5751/ACE-01657-150211

Copyright (C) 2020 by the author(s). Published here under license by the Resilience Alliance.

Research Paper

\title{
Nest box location determines the exposure of the host to ectoparasites
}

Jesús Veiga ${ }^{1}$ (D) and Francisco Valera ${ }^{1}$

${ }^{1}$ Departamento de Ecología Funcional y Evolutiva, Estación Experimental de Zonas Áridas (EEZA-CSIC), Almería, Spain

\begin{abstract}
Nest box supplementation is a widely used technique to aid in the conservation of cavity nesting bird species. However, the criteria to choose the best location for nest boxes has seldom considered the likely exposure of cavity-users to parasites. Birds host an impressive diversity of ectoparasites that may have detrimental effects on their fitness. Here we focus on the ectoparasite infracommunity of a secondary cavity nesting bird species, the European Roller (Coracias garrulus), breeding in nest boxes in a semiarid environment. During three breeding seasons, we examined the composition and abundance of parasites at the nest level and explored their spatial structure and the effect of nest-site type, breeding phenology, and host number (brood mass) on the variability of the infracommunity. Nest location (nest boxes on trees vs nests on cliffs and human constructions) contributed the most to explain differences in prevalence and abundance of the various ectoparasite species during the three years. Host breeding phenology consistently affected the abundance of the most prevalent and abundant ectoparasite (Carnus hemapterus) and also the abundance of biting midges and blackflies, but only during some years. Host brood mass had no significant influence on any ectoparasite. Neither the occurrence nor the abundance of the infracommunity of parasites had a significant spatial structure. This study, performed at the host population scale, reveals that the socioenvironmental characteristics resulting from the selection of nest-site microhabitat explain most of the variation of the ectoparasite infracommunity. Accordingly, nest boxes for vulnerable species should be placed with solid knowledge of the effect of such features.
\end{abstract}

\section{L'emplacement du nichoir détermine l'exposition de l'hôte aux ectoparasites}

RÉSUMÉ. On installe très souvent des nichoirs pour aider à la conservation des espèces d'oiseaux cavicoles. Toutefois, les critères pour l'emplacement des nichoirs ont rarement pris en compte l'exposition probable des utilisateurs de cavités aux parasites. Les oiseaux sont les hôtes d'une diversité impressionnante d'ectoparasites qui peuvent avoir des effets néfastes sur leur santé. Dans la présente étude, nous examinons l'infracommunauté d'ectoparasites d'une espèce d'oiseaux nicheurs utilisatrice secondaire de cavités, le Rollier d'Europe (Coracias garrulus), qui niche dans des nichoirs en milieu semi-aride. Durant trois saisons de reproduction, nous avons étudié la composition et l'abondance des parasites à l'échelle du nid et exploré leur structure spatiale ainsi que l'effet du type de site de nidification, de la phénologie de reproduction et du nombre d'hôtes (masse des couvées) sur la variabilité de l'infracommunauté. L'emplacement des nids (nichoirs sur les arbres par rapport aux nids sur les falaises et les constructions humaines) a contribué le plus à expliquer les différences de prévalence et d'abondance des diverses espèces d'ectoparasites au cours des trois années. La phénologie de reproduction de l'hôte a eu un effet systématique sur l'abondance de l'ectoparasite le plus fréquent et le plus abondant (Carnus hemapterus), de même que sur celle des moucherons piqueurs et des mouches noires, mais seulement lors de certaines années. La masse de la couvée hôte n'a pas eu d'influence significative sur aucun ectoparasite. Ni la présence ni l'abondance de l'infracommunauté de parasites n'avaient une structure spatiale significative. Cette étude, réalisée à l'échelle de la population hôte, révèle que les caractéristiques socioenvironnementales résultant de la sélection du microhabitat du site de nidification expliquent la plupart des variations observées chez l'infracommunauté d'ectoparasites. Par conséquent, les nichoirs destinés aux espèces vulnérables doivent être placés avec une connaissance solide de l'effet de ces caractéristiques.

Key Words: arid areas; Carnus hemapterus; conservation; Coracias garrulus; ectoparasite; infracommunity; nest box; nest-site

\section{INTRODUCTION}

Nest site supplementation by addition of nest boxes has become an increasingly common restoration strategy that has proved to promote population increases of threatened species (e.g. Václav et al. 2011, Berthier et al. 2012). However, a number of shortfalls have also been reported (see Klein et al. 2007, Valera et al. 2019). To date, only limited research has considered whether the location of nest boxes influences the exposure of birds to parasites. Ectoparasites are a taxonomically diverse group of organisms able to affect the hosts' fitness (Lehmann 1993) and provoke antiparasitic adaptations by their hosts (Clayton et al. 2010). Birds are known to host a wide array of ectoparasites (Clayton et al. 2010), many of which are vectors of pathogens, e.g., avian malaria and closely related parasites transmitted by Culex mosquitoes, biting midges, and louse flies (Valkiunas 2004) that also have detrimental effects on their hosts (Merino et al. 2000, Marzal et al. 2005, Valkiŭnas et al. 2006, Martínez-de la Puente et al. 2010, Asghar et al. 2015). In fact, the abundance of ectoparasites is a key epidemiological variable (Sol et al. 2000, Martínez-de la Puente et al. 2013).

Address of Correspondent: Jesús Veiga, Estación Experimental de Zonas Áridas, Ctra. De Sacramento S/n, La Cañada De San Urbano, Almería , Spain, E-04120, jveiga@eeza.csic.es 
Much research has been dedicated to exploring the factors accounting for the prevalence and abundance of specific ectoparasitic species or families (for ticks see Oorebeek and Kleindorfer 2008, for biting midges and blackflies see Martínezde la Puente et al. 2009a, for mites, fleas, and blowflies see Merino and Potti 1996; Cantarero et al. 2013, Griebel et al. 2020) on different bird species. However, a given host species or individual (adult, nestling, infested nest) usually hosts a variety of ectoparasitic species, the ectoparasite infracommunity (Bush et al. 1997). Considering this level of organization is important because, for instance, it is mainly within the framework of the infracommunity where interactions among different parasite species occur (Poulin 2007) and such interactions can influence the structure of the infracommunity (Heeb et al. 2000). Thus, analyzing separately a given ectoparasite species gives an incomplete picture of the factors influencing that ectoparasite and, in turn, the host.

Optimally, the ectoparasite community should be studied as a whole, what could give deeper insights into the underlying mechanisms ruling variations in composition and abundance. For instance, studies focused on some ectoparasite taxa have shown that factors such as distance at large scale (Gómez-Díaz et al. 2008 on birds) or locality features (Lareschi and Krasnov 2010 on mammals), host characteristics (Krasnov et al. 2008, Lareschi and Krasnov 2010, Sponchiado et al. 2017 on mammals), off-host environment such as temperature and precipitation (Krasnov et al. 2005, 2008 on mammals), or habitat characteristics (Manzoli et al. 2013 on birds) are partly responsible for the variation in the ectoparasite community. Yet, comprehensive studies on the ectoparasitic community of bird species are scarce (see Hamstra and Badyaev 2009, and Lareschi and Krasnov 2010, Sponchiado et al. 2017 for a similar approach on rodents and marsupials). Such scarcity is partly because of the fact that studying different ectoparasite species (each of them with different life cycles, requirements, and adaptations) is methodological and logistically complicated. However, cavitynesting birds offer an excellent opportunity to address this issue. They usually host a wide variety of ectoparasites (Marshall 1981), some of which are nidicolous, whereas others visit the nest temporarily to feed on the adults and/or nestlings. Thus, studying the nests of hole-breeding birds facilitates the investigation of the ectoparasitic community.

The European Roller Coracias garrulus (hereafter roller) is a migratory, secondary cavity-nesting species breeding in sandy cliffs, tree holes, human constructions, and artificial nest boxes (Cramp 1998). This species has been of conservation concern for years given its decline in Europe from the last decades of the 20th century (BirdLife International 2019). Subsequent conservation efforts (mainly artificial nesting sites provisioning) have led to the recovery of the species in several European countries and its current protection status is "Least Concern" (BirdLife International 2019). However, given the dependence of the species on continued management actions, e.g., nest box schemes (Rohlf et al. 2014), it has been proposed as a "conservation-reliant species" (Gameiro et al. 2020). Several ectoparasites have been described for this species: carnid flies (Carnus hemapterus; Calero-Torralbo et al. 2013, Václav et al. 2016), biting midges, blackflies, and sandflies (Václav et al. 2016, Veiga et al. 2018), hematophagous mites (Václav et al. 2008, Roy et al. 2009), lice (Sosnowski and Chmielewski 1996), louse flies (Nartshuk and Matyukhin 2019, Veiga et al. 2019a), and ticks (Hoogstraal and Kaiser 1961, Tsapko 2017). Specific studies on these ectoparasites show that factors such as host body features (Clayton and Walther 2001, Valera et al. 2004, Martínez-de la Puente et al. 2009b, Václav and Valera 2018), breeding phenology (Martínez-de la Puente et al. 2009a, Calero-Torralbo et al. 2013), or habitat characteristics (Černý et al. 2011, Manzoli et al. 2013) account for variation in their abundance and prevalence.

In this paper, we examine the ectoparasites of rollers breeding in nest boxes in a semiarid landscape over three breeding seasons. We focus on the effect of nest box location, breeding phenology, and brood mass on the composition and abundance of ectoparasites at the infracommunity level (nest), its variation, and spatial distribution. We evaluate the relative importance of offhost and host related variables on the exposure of the avian host to ectoparasites. Finally, we discuss the implications of our results for conservation of rollers and other cavity-nesting species.

\section{METHODS}

\section{Study area}

The study area $\left(\sim 50 \mathrm{~km}^{2}\right)$ is located in the Desert of Tabernas (Almería, SE Spain, $37^{\circ} 05^{\prime} \mathrm{N}, 2^{\circ} 21^{\prime} \mathrm{W}$ ). The landscape mostly consists of badlands and wadis with olive and almond groves interspersed among dry watercourses. The climate is semiarid with mild winters, long hot summers, and low average annual rainfall $(235 \mathrm{~mm})$ with strong inter- and intra-annual variation (Lázaro et al. 2001).

During this study rainfall varied broadly (accumulated precipitation during the hydrologic year 1 October -30 September: $2016=100.4 \mathrm{~mm} ; 2017=334.8 \mathrm{~mm} ; 2018=200.2$ $\mathrm{mm}$ ), with 2016 being a dry year and 2017 a very rainy one.

\section{Study system}

The European Roller used to breed in our study area in burrows excavated by the European Bee-eater (Merops apiaster) in sandstone cliffs or in cavities in human constructions. A nest box supplementation program starting in 2005 (Václav et al. 2011) showed that rollers were limited by the availability of nesting sites. Maintenance of the nest box scheme has made the roller the most common cavity nester in the area and, during the study, most of the roller population bred in nest boxes located on trees, sandstone cliffs, and human constructions (Valera et al. 2019). Nest boxes on trees were usually isolated from other breeding bird species, which mostly consisted of open nesters including the Eurasian Collared Dove (Streptopelia decaocto) and Common Wood Pigeon (Columba palumbus). In contrast, nest boxes located on sandstone cliffs were usually near other natural cavities occupied by cavity-nesting birds such as Common Kestrels (Falco tinnunculus), Jackdaws (Corvus monedula), Rock Pigeons (Columba livia), and Little Owls (Athene noctua). Similarly, nest boxes on farmhouses were usually neighbors to bird species breeding in cavities and crevices such as Rock Pigeons, Common Kestrels, Spotless Starlings (Sturnus unicolor), and House Sparrows (Passer domesticus). Another common feature of nest boxes on sandstone cliffs and farmhouses was that they were located on devegetated surface, while nest boxes on trees were covered by dense tree canopy. 
During the three breeding seasons under study (2016-2018) 61, 60 , and 59 nest boxes were available for rollers, respectively. Nest boxes were kept in the same places all three years. On average, about $60 \%$ of the nest boxes were occupied by rollers (range: $58 \%-63 \%$ ), the rest were occupied by other species (Spotless Starlings, House Sparrows, Little Owls, Scops Owls [Otus scops]) or were not used. Nest boxes on trees, cliffs, and human constructions were frequently interspersed so that, averaging data from the ones occupied during the study period, in $57 \%$ (range: $48 \%-62 \%$ ) of the cases the nearest nest box neighbor of a focal nest was in the same nest site location (e.g., tree-tree or cliff-cliff), whereas the remaining 43\% (range: 52\%-38\%) were in a different location (e.g., tree-farmhouse, tree-cliff, farmhouse-cliff).

Rollers nest in unlined holes where they lay the eggs directly on the bottom of the cavity. They rear a single brood per year, and egg hatching is distinctly asynchronous with remarkable annual differences in hatching date and in clutch and brood size (Václav et al. 2008, 2011). In our population, incubation takes 21 days and nestling rollers fledge approximately 20-22 days after hatching (Václav et al. 2011).

Rollers in our study area were parasitized at least by biting midges (Fam. Ceratopogonoidae), blackflies (Fam. Simuliidae), sandflies (Fam. Psychodidae), carnid flies (Fam. Carnidae), louse flies (Fam. Hippoboscidae), hematophagous mites (Fam. Macronyssidae and Fam. Dermanyssidae), and soft ticks (Fam. Argasidae). Because each group of ectoparasites has different habits, mobility and strategies of host exploitation, e.g., nidicolous vs temporary parasites, diurnal vs nocturnal, different methods were required for estimating their respective abundances.

\section{Routine fieldwork}

The reproduction of rollers and their ectoparasite community was studied in 31,37 , and 36 nest boxes during the breeding seasons of 2016, 2017, and 2018, respectively (although the sample size decreased because of the occurrence of noninfested nests or nests where the abundance of some parasites was not estimated). Occupied nest boxes were followed closely from occupancy (end of April) until fledging and inspected periodically during egg laying, incubation, hatching, and nestling development. At least three visits were made every year during the nestling phase: the first one to place a sticky trap, the second one to remove the trap, and the third to ring the fledglings. The number of nestlings was recorded in each visit. We also measured the mass of roller nestlings (with $0.1 \mathrm{~g}$ accuracy) when the oldest nestling of each nest was $\sim 13$ days old.

Prior to each breeding season, nests were emptied, cleaned with soap, and disinsected with a solution of $10 \mathrm{ml} / \mathrm{L}$ of Arpon ${ }^{\circledR}$ (cipermetrine). The solution was sprayed on the nest's inner surface and walls. This insecticide has been proved to be highly efficient against Carnus hemapterus (prevalence in treated boxes: $0 \%$, Amat-Valero et al. 2012) and other insects. Thus, infestation in a given year did not affect the next year. After fumigation, each nest was provided with fresh, clean sand (the usual substratum in natural cavities in our study area).

During 2018, a thermal pad was placed on the inner wall of 18 nest boxes during the nestlings phase (day 6 to day 21 , day $1=$ hatching date of the first egg) for a different study. Its effect on microclimate was not significant and subdued by factors such as nest orientation or nest location. Nevertheless, we tested the effect of the thermal pads on the occurrence and abundance of the ectoparasites via redundancy analysis (RDA). We found that thermal pads had no significant effect in any model $(\mathrm{P}>0.3)$.

\section{Ectoparasite sampling}

Winged diptera visiting the host temporarily (biting midges, blackflies, and sandflies) were sampled by means of sticky traps placed under the upper lid of the nest boxes (Tomás et al. 2008). This method has been found reliable and effective for sampling small flying insects that are captured while entering or leaving the nest. Sticky traps were placed when the oldest nestling of each nest was $\sim 13$ days old (2016: mean $=12.9$, range $=11-17 ; 2017$ : mean $=13.57$, range $=11-19 ; 2018:$ mean $=13.83$, range $=13$ 19). Sticky traps were maintained three days in 2016 (trap size $=$ $\left.57,6 \mathrm{~cm}^{2}\right)$ and four days in $2017\left(\right.$ trap size $\left.=80 \mathrm{~cm}^{2}\right)$ and $2018($ trap size $=330 \mathrm{~cm}^{2}$ ). The number of ectoparasites captured by the sticky traps was then standardized to captures per day per $\mathrm{cm}^{2}$.

Carnus hemapterus (hereafter Carnus) is a nidicolous ectoparasite that parasitizes nestlings of many bird species but it may also attack adult birds during incubation (López-Rull et al. 2007). Carnid flies are winged when emerged from the pupa and during dispersal (Veiga et al. 2019b) but they lose the wings when a suitable host is found. Then, flies remain on the nestlings and in the nest debris. Therefore, sticky traps are not suitable to estimate the abundance of carnid flies. Instead, direct estimation of wingless carnid flies during the peak infestation phase (when nestlings have sheaths, see Václav et al. 2008, Václav and Valera 2018) is a reliable method (see Roulin 1998). Carnus estimation in each nest was done when the older nestling was $\sim 13$ days old (Václav et al. 2008). Roller nestlings were carefully taken from the nest and placed in a cotton bag. Subsequently, each nestling was examined and the number of carnid flies was counted twice. Both counts were averaged. The number of carnid flies that remained in the nest debris (even if small, mean $=4.3 \%$, see Veiga et al. 2020) was also counted and added to the sum of the number of carnid flies in all nestlings to get the total number of Carnus flies inside the nest.

Louse flies are robust flying insects and they can probably escape from the sticky traps. Thus, they were estimated following the same method employed for carnid flies. However, because they are not nidicolous and are highly mobile parasites, their detection during a single visit is unlikely and, thus, we screened all the nestlings in search of louse flies upon every visit. Furthermore, in some cases we took advantage of adults captured brooding the nestlings to check the presence of louse flies too, exploring carefully between the feathers. This method probably gives accurate estimates of prevalence but not of abundance, which can be easily underestimated because of the high mobility and escape behavior of louse flies (Veiga et al. 2019a).

Regarding hematophagous mites, we recorded the occurrence of Pellonyssus reedi, Ornithonyssus sylviarum, Dermanyssus gallinae, and Dermanyssus hirundinis in nest boxes occupied by rollers. In general, hematophagous mites have short generation times. They are able to reach high numbers rapidly (Pacejka et al. 1996, Proctor and Owens 2000), so that they are easier to detect when 
nestlings are grown, but their abundance is highly variable. Similar to louse flies, we took advantage of successive monitoring of the nestlings along the breeding cycle to detect parasitic mites.

Argasidae ticks were usually found under the lid of nest boxes. They also become more abundant along the nestling phase (see, for instance, Dupraz et al. 2017). We recorded their presence during the routine checks of nestlings.

Louse flies, hematophagous mites, and soft ticks had low prevalence in our study area, and a reliable estimation on their abundance requires specific and demanding surveys. Therefore, we only analyzed their prevalence.

After discarding the nests where no ectoparasites were found and those where the abundance of some ectoparasites was not estimated, the sample size for the three study years was 30,36 , and 36 for presence-absence data and 29, 36, and 36 for abundance data, respectively.

\section{Statistical analysis}

The ectoparasite infracommunity was analyzed in terms of species prevalence (presence-absence of biting midges, blackflies, sandflies, carnid flies, louse flies, hematophagous flies, and ticks) and abundance (of biting midges, blackflies, sandflies, and carnid flies). To control for the effect of the different sampling methods, the abundance of a given parasite group in each nest was scaled by dividing it by the maximum value of that parasite group in all the nests. This transformed variable was used in all the analyses.

In order to test whether geographical location of nests accounted for variations in the ectoparasite infracommunity, Moran's eigenvector maps (MEM) were performed on both the presenceabsence and abundance data in each year. MEM analyses are considered robust and suitable for discriminating between spatial and environmental effects on community composition (Griffith and Peres-Neto 2006). This method computes the principal coordinates of a matrix of distances among geographic neighbors, i.e., geographic connectivity matrices among sampling sites (Borcard et al. 2011). MEM decomposes the spatial relationships into eigenvectors, which represent the variation at specific spatial scales. First, we explored for each year whether there was significant linear relationships between the infracommunity composition or abundance data and the geographical coordinates. Because no relationship was found we worked on nondetrended data (Borcard et al. 2004). Then, we selected the eigenvectors describing significant spatial autocorrelation (only positive eigenvalues, see Dray et al. 2006). Constrained canonical analyses (CCA; for presence-absence data) and redundancy analyses (RDA; for abundance data) were run for each year with the corresponding set of eigenvectors selected. According to Borcard et al. (2004) forward selection of the MEM eigenvectors should follow in those ordination analyses (CCA or RDA) that proved significant. Selection of eigenvectors in nonsignificant cases would lead to spurious models. The forward-selected eigenvectors should then be included in the final CCA and RDA to compare the effect of socioenvironmental and distance-related variables.

Ordination analysis is an adequate method to examine complex ecological data sets (Legendre and Legendre 2012). In order to examine how environmental and host-related parameters contributed to explain the variation of the ectoparasite infracommunity, CCA (for presence/absence of all parasite groups) and RDA (for abundance of carnid flies, blackflies, biting midges, and sandflies) were used. In these analyses, brood mass (sum of the mass of all nestlings at day 13), nest location (cliff, tree, farmhouse), and breeding phenology (hatching date of the first egg in the population $=1$, calculated separately for each year) were included as constraining variables. Brood mass and breeding phenology were scaled and centered before being included in the analyses. Forward selection was applied to the overall models to increase parsimony and reduce correlation between explanatory variables. ANOVA-like permutation tests with 999 permutations were employed to assess the significance of the models and constraining variables. Analyses (CCA and RDA) were run separately for each study year. All analyses and plotting were conducted with R software 3.6.1 (R Core Team 2019), using the packages vegan (Oksanen et al. 2019), PCNM (Legendre et al. 2012), and MASS (Venables and Ripley 2002).

\section{RESULTS}

\section{Spatial analysis}

CCA analyses (for presence-absence data) with the set of selected eigenvectors for each year were nonsignificant in all cases (2016: $\mathrm{F}_{7,22}=1.37, \mathrm{P}=0.11 ; 2017: \mathrm{F}_{8,27}=0.87, \mathrm{P}=0.69 ; 2018: \mathrm{F}_{9,26}=$ $1.24, \mathrm{P}=0.18$ ), so the procedure was stopped because no significant spatial structure was detected. Concerning the abundance of ectoparasites, no spatial structure was found in any of the three study years either (RDA analyses: $2016: \mathrm{F}_{7,21}=1.07$, $\left.\mathrm{P}=0.39 ; 2017: \mathrm{F}_{8,27}=0.59, \mathrm{P}=0.95 ; 2018: \mathrm{F}_{9,26}=1.34, \mathrm{P}=0.17\right)$.

\section{Determinants of the variation in the composition of the ectoparasite infracommunity}

CCAs on the presence-absence of the seven ectoparasitic groups rendered significant overall models in each year (Table 1). Forward selection retained the variable nest location to explain the variation on the occurrence of ectoparasites in all the study years, but phenology was also retained in 2017 (Table 1). Brood mass was never selected.

Table 1. Permutation tests for the constrained canonical analyses (CCA) in each study year. F-values, degrees of freedom, and P values of the global models, the selected models, and the corresponding variables selected are shown. The variance explained $(\%)$ by each selected model is also offered.

\begin{tabular}{|c|c|c|c|c|c|c|}
\hline & \multicolumn{2}{|l|}{2016} & \multicolumn{2}{|l|}{2017} & \multicolumn{2}{|l|}{2018} \\
\hline & $F(d f)$ & $\begin{array}{c}\mathrm{P} \\
\text { value }\end{array}$ & $F(d f)$ & $\begin{array}{c}\mathrm{P} \\
\text { value }\end{array}$ & $F(d f)$ & $\begin{array}{c}\mathrm{P} \\
\text { value }\end{array}$ \\
\hline Global model & $3.23(4,25)$ & 0.001 & $2.54(4,31)$ & 0.002 & $3.89(4,31)$ & 0.001 \\
\hline Selected model & $5.22(2,27)$ & 0.001 & $3.35(3,32)$ & 0.001 & $5.71(2,33)$ & 0.001 \\
\hline Nest box location & $5.22(2,27)$ & 0.001 & $3.85(2,32)$ & 0.001 & $5.71(2,33)$ & 0.001 \\
\hline Phenology & - & - & $2.36(1,32)$ & 0.03 & - & - \\
\hline $\begin{array}{l}\text { Explained } \\
\text { variance }\end{array}$ & $28 \%$ & & $24 \%$ & & $26 \%$ & \\
\hline
\end{tabular}

The selected models included two significant CCA axes in 2016, whereas only the first axis was significant in 2017 and 2018 (Table A1.1). These models accounted on average for $26 \%$ of variation (range: $24 \%-28 \%$; Table 1). 
Fig. 1. Constrained canonical analyses on the effect of nest box location and phenology on the composition of the ectoparasite infracommunity of breeding European Rollers (Coracias garrulus) in southeastern Spain during (a) 2016, (b) 2017, (c) 2018. The canonical correspondence correlation biplot (scaling 2) shows the relation between the constraining (blue arrows, crosses, ellipses, and labels) and the response variables (black crosses, lines, and labels). The blue crosses of the three levels of the explanatory variable (nest box location) represent the centroids of each level, and the blue ellipses depict 95\% confidence limits for the SE of these centroids.
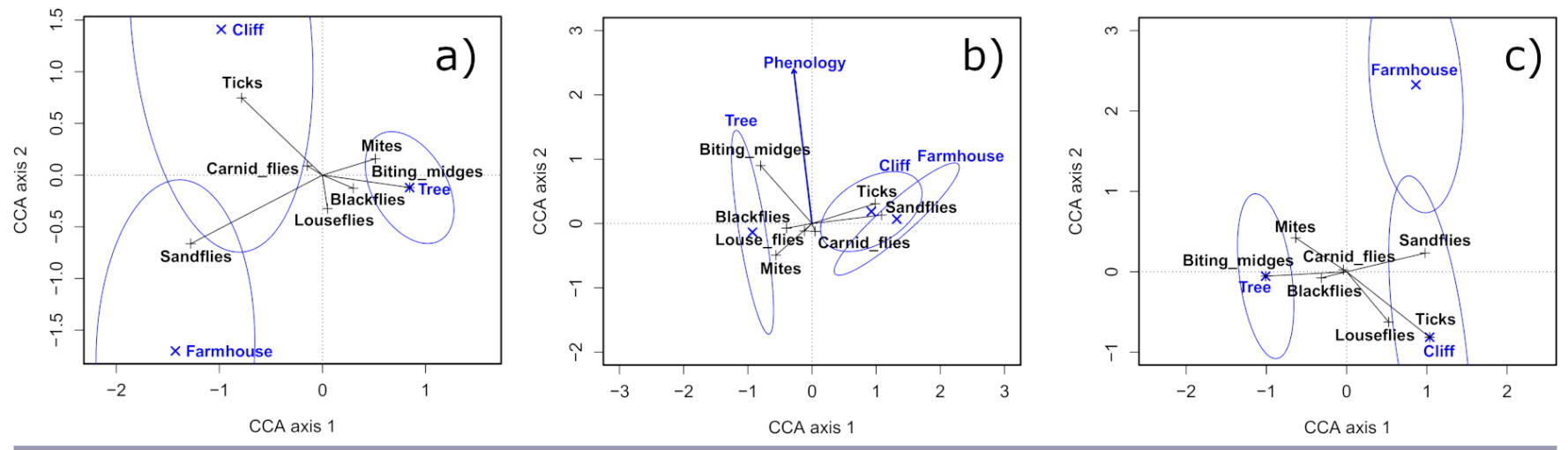

Nest location contributed significantly to explain the variation in ectoparasite community composition so that in all three years the occurrence of blackflies, biting midges, and hematophagous mites was associated to nest boxes on trees (Fig. 1a-c). In contrast, ticks occurred preferentially in nest boxes on cliffs, and sandflies in nest boxes on cliffs and farmhouses (Fig. 1a-c). The presence of carnid flies and louse flies was not related to nest location (Fig. 1a-c). Phenology also contributed significantly to explain the variation in ectoparasite community composition but only in the humid year (2017), when the occurrence of biting midges increased along the season (Fig. 1b).

\section{Determinants of the variation in the abundance of the ectoparasite infracommunity}

RDAs on the abundance of the four ectoparasitic groups rendered significant overall models in all three years (Table 2). Forward selection retained the variables nest location and phenology to explain the variation on the abundance of ectoparasites in the three years (Table 2). Brood mass was not selected in any study year.

The selected models included two significant RDA axes in 2016 and 2017, whereas only the first axis was significant in 2018 (Table A1.2). The models selected accounted on average for $29 \%$ of variation (range: $23 \%-36 \%$; Table 2).

Nest location contributed significantly to explain the variation in ectoparasite community composition during all the study years (Table 2) so that nests on cliffs and farmhouses had higher abundance of carnid flies and sandflies (Fig. 2a-c). Conversely, nests on trees held higher abundances of biting midges and blackflies (Fig. 2a-c). Breeding phenology also contributed significantly to explaining the variation of abundance of ectoparasites (Table 2), affecting negatively the abundance of Carnus hemapterus in all three years and also the abundance of blackflies in 2016 and 2017. Biting midges increased over the breeding season in 2017 (Fig. 2b).
Table 2. Permutation tests for the redundancy analyses (RDA) in each study year. F-values, degrees of freedom, and $\mathrm{P}$ values of the global models, the selected models, and the corresponding variables selected are shown. The variance explained (\%) by each selected model is also offered.

\begin{tabular}{|c|c|c|c|c|c|c|}
\hline & \multicolumn{2}{|l|}{2016} & \multicolumn{2}{|l|}{2017} & \multicolumn{2}{|l|}{2018} \\
\hline & $F(d f)$ & $\begin{array}{c}\mathrm{P} \\
\text { value }\end{array}$ & $F(d f)$ & $\begin{array}{c}\mathrm{P} \\
\text { value }\end{array}$ & $F(d f)$ & $\begin{array}{c}\mathrm{P} \\
\text { value }\end{array}$ \\
\hline Global model & $3.84(4,24)$ & 0.001 & $2.39(4,31)$ & 0.008 & $3.66(4,31)$ & 0.001 \\
\hline Selected model & $4.66(3,25)$ & 0.001 & $3.21(3,32)$ & 0.002 & $4.35(3,32)$ & 0.001 \\
\hline Nest box location & $5.50(2,25)$ & 0.003 & $2.82(2,32)$ & 0.002 & $4.86(2,32)$ & 0.002 \\
\hline Phenology & $2.97(1,25)$ & 0.039 & $3.97(1,32)$ & 0.010 & $3.32(1,32)$ & 0.036 \\
\hline $\begin{array}{l}\text { Explained } \\
\text { variance }\end{array}$ & $36 \%$ & & $23 \%$ & & $29 \%$ & \\
\hline
\end{tabular}

\section{DISCUSSION}

The number of conservation-reliant species (those fully dependent on continued management actions) is increasing because of human activities (Scott et al. 2010). Whereas some conservation actions, e.g. nest box installation, can be very effective, they may lead to permanent human dependence of some species. Gameiro et al. (2020) showed that $>65 \%$ of Portuguese Lesser Kestrels (Falco naumanni) and European Rollers breeding pairs currently nest in artificial nest sites. Alternative methods should be implemented to avoid such dependence, e.g., natural cavity restoration (Valera et al. 2019), but, meanwhile, the consequences of artificial breeding for a large fraction of the population of some species should be carefully considered (see, for instance, Griebel et al. 2020). However, the criteria to install nest boxes are not always clear (e.g., Klein et al. 2007, Rodríguez et al. 2011) and, to our knowledge, the exposure of cavity-nesting bird species to parasites due to the location of nest boxes has seldom been considered. This study reveals that habitat characteristics at small scale (nest box location), more than geographical or host-related traits, e.g., brood mass, determine the assemblage of ectoparasites of a cavity-nesting bird species. 
Fig. 2. Redundancy analyses on the effect of breeding phenology and nest box location on the abundance of ectoparasites of breeding European Rollers (Coracias garrulus) in southeastern Spain during (a) 2016, (b) 2017, (c) 2018. Redundancy analysis correlation biplot (scaling 2) shows the relation between the constraining (blue arrows, crosses, ellipses, and labels) and response variables (black crosses, lines, and labels). The blue crosses of the three levels of the explanatory variable (nest box location) represent the centroids of the variable, and the blue ellipses denote $95 \%$ confidence limits for the SE of these centroids.
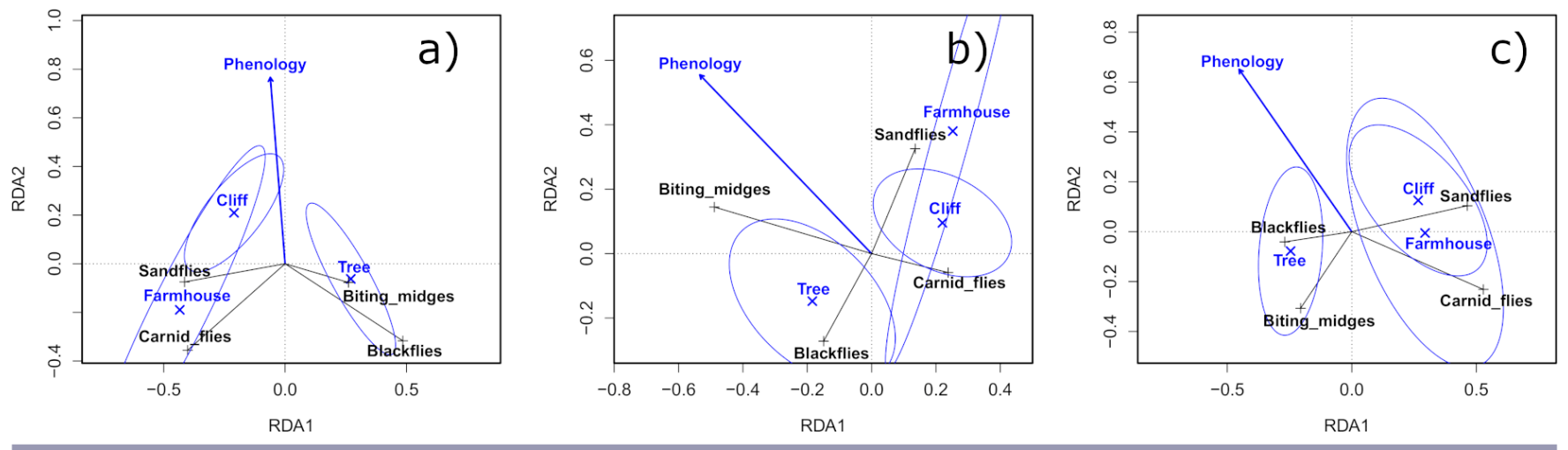

We did not find any spatial structure neither in the occurrence nor in the abundance of the ectoparasite infracommunity. A strong effect of location and distance has been found at large scales (hundreds or thousands of $\mathrm{km}$ ) where environmental conditions differ substantially (Gómez-Díaz et al. 2008, Krasnov et al. 2008). However, at smaller spatial scales the effect of locality on ectoparasites richness and abundances has been reported (Lareschi and Krasnov 2010) together with factors such as microclimate, habitat characteristics at mesoscale, or host-related features (Poulin 2004, Kleindorfer and Dudaniec 2009, Krasnov et al. 2015, Kleindorfer et al. 2016, Dube et al. 2018). Given that water availability and moist habitats determine the distribution and abundance of biting midges, mosquitoes, and blackflies (Braverman et al. 1974, Ferraguti et al. 2016), and given the large interannual differences in precipitation, we expected some geographical pattern associated with the proximity of temporary water courses or ponds to some nests, at least in some year(s). However, the spatial scale of our study and the high dispersal abilities of most of the study species (Crosskey 1990, Murray and Kirkland 1995, Veiga et al. 2020) may account for the lack of a clear spatial pattern of the ectoparasite infracommunity.

Brood mass seemingly had no effect on the variation of the ectoparasite infracommunity either. Previous studies did find a relationship between brood mass or brood size and the abundance of some ectoparasites (see, for instance, Veiga et al. 2020 for Carnus hemapterus, and Martínez-de la Puente et al. $2009 \mathrm{~b}$ for biting midges), probably because of an associated increase in host cues or food availability. Nonetheless, this variable could contribute similarly to all the ectoparasite taxa studied here, thus increasing their abundances in a similar fashion.

In contrast, nest location (habitat characteristics close to the nest boxes) was the most important variable defining the spatial distribution of ectoparasites in all three years. This is particularly interesting because the various types of locations of nests in our study area were interspersed, so that a nest box in a given habitat, e.g., trees, could be closer to another in a very different one, e.g., cliff. Because this could influence host detection and facilitate infestation, we would expect similar infracommunities in neighboring nest boxes. However, this was not always the case. Ticks occurred almost exclusively in nest boxes on cliffs $(78.6 \%$ of the infested nests, $\mathrm{n}=14$ ) whereas hematophagous mites selected nest boxes on trees $(81.8 \%$ of the infested nests, $n=18)$. Blackflies and biting midges were more frequently found and were more abundant in nest boxes on trees whereas sandflies were more prevalent and abundant in nest boxes on cliffs and farmhouses. The prevalence of other parasites (carnid flies and louse flies), did not seem to be affected by the habitat around the nest, although Carnus was more abundant in nest boxes on cliffs and farmhouses.

Habitat requirements and preferences of ectoparasites, e.g., humidity and temperature (see Heeb et al. 2000, Goodenough et al. 2011, Amat-Valero et al. 2014) may account for some of our results. For instance, the preferences of blackflies and biting midges for nest boxes located on trees correspond with previous studies reporting their selection of tree canopies for resting (Carpenter et al. 2008, Černý et al. 2011). Similarly, sandflies use undergrowth, rock crevices, animal burrows, and human dwellings as resting sites during the daytime (Lane 1993). In our study area, these microhabitats are mostly found in cliffs and farmhouses.

The social environment of the host may also influence the rollers' ectoparasite infracommunity. For example, most Argasidae ticks are nest, burrow, or roost parasites (Klompen et al. 1996), and Argas reflexus, the most common species in our study area, is frequently found on pigeons (Dautel et al. 1999), but also on Little Owls and Jackdaws (Murillo et al. 2013; personal observations). In our study area, these bird species usually breed in crevices and cavities on cliffs, therefore the social environment of rollers breeding on sandcliffs could be responsible for the higher prevalence of ticks.

The higher prevalence of hematophagous mites (a contacttransmitted parasite) in nest boxes on trees could also be explained by social factors such as the preferential occupation of such nest boxes by starlings, a common host of hematophagous mites (Błoszyk et al. 2016). Infected starlings occupying nest boxes prior 
to rollers' arrival could help the colonization of the box by mites that could subsequently attack rollers breeding in the same nest box. No breeding attempt of starlings in nest boxes on cliffs or farmhouses has been registered in our study area for 14 years.

The high prevalence of carnid flies $(92 \%, \mathrm{n}=104)$ can be explained by their remarkable dispersal ability (Veiga et al. 2020). Their higher abundance in nests on cliffs and farmhouses than in nests on trees was also reported by these authors. Veiga et al. (2020) also found that Carnus abundance was positively related to the density of other potential neighboring host species, which was higher in cliffs and farmhouses than on trees.

Our analyses revealed that breeding phenology contributed to explaining the variation in prevalence and/or abundance of some parasites. The most consistent result refers to Carnus, for which we found a negative relationship between abundance and phenology all three years. This was also the case for blackflies but only in 2016 and 2017. In contrast, biting midges increased their occurrence and abundance along the season but only during the humid year (2017). Calero-Torralbo et al. (2013) also found a negative effect of phenology on the abundance of Carnus and suggested that its early emergence enhanced the probability of host finding at the beginning of the breeding season. The higher prevalence and abundance of biting midges along the season during the humid year can be related to the higher availability of breeding sites (see Martínez-de la Puente et al. 2009a). In contrast, the seasonal decrease in the number of blackflies could be related to the disappearance of temporary streams that are required for breeding. Yet, this effect was observed in the driest and most humid year and not in the average one. Aspects such as the effect of some parasite species on others via microclimate modification (Heeb et al. 2000) or interannual differences in the distribution of rainfall throughout the year (Veiga and Valera 2020) can also account for the patterns found.

\section{IMPLICATIONS FOR CONSERVATION}

Our results show the effect of the local environment on the ectoparasite infracommunity of a bird species of conservation concern. In spite of large differences in key variables like precipitation, nest box location consistently accounted for most of the variance in prevalence and abundance of various ectoparasite species and this occurred apparently via (i) the habitat requirements and preferences of ectoparasites, and (ii) the social environment of the host: the preferential occupation (prior to the arrival of the focal species) of some nest locations by other cavity bird species and the identity and density of neighboring breeding birds could favor or exclude some ectoparasite species.

How can this knowledge contribute to the conservation of the roller and other endangered species? Some bird species are thought to imprint on nest type, such that future nest preferences are influenced by natal experiences (White et al. 2002, Stamps and Swaisgood 2007). For instance, the delay in the recovery of the tree-nesting peregrines in Germany has been attributed to the practice of restoring only cliff and building-imprinted populations (Kirmse 2001, Wegner et al. 2005). We ignore whether rollers can become imprinted on nest boxes in a certain location. If so, they would be regularly exposed to the ectoparasites associated with that location. But even if imprinting does not occur, knowing of such associations is important. We do know if nest box provisioning may lead to desertion of natural cavities by rollers (Valera et al. 2019). Because carnid flies are more abundant in nest boxes than in natural cavities (Calero-Torralbo et al. 2013) and also more abundant in nest boxes on cliffs, nest box schemes could result in a greater exposure of rollers to this parasite, which can affect nestling body condition, immunocompetence, and survival (Hoi et al. 2018 and references therein). In contrast, preferential placement (and usage) of nest boxes on trees would increase the exposure of birds to vector-borne diseases, e.g., avian malaria transmitted by blackflies and biting midges). Information offered here could provide guidance to avoid the locations that favor the most abundant or detrimental local parasites and pathogens.

Responses to this article can be read online at: http://www.ace-eco.org/issues/responses.php/1657

\section{Acknowledgments:}

We thank Stanislav Kolencik and Francisco Castaño Vázquez for their help with fieldwork. Peter Masan kindly identified mites and Radovan Václav gave useful advice. We thank two anonymous referees for their constructive criticism. Junta de Andalucia provided permits to sample birds and their nests. F. $V$. received financial support from the projects CGL2014-55969 and PGC2018-097426B-C22 (MCIUIAEI/FEDER, UE). J.V. was funded by a predoctoral grant (BES-2015-075951) of the Spanish Ministry of Economy, Industry and Competitiveness.

\section{LITERATURE CITED}

Amat-Valero, M., M. A. Calero-Torralbo, R. Václav, and F. Valera. 2014. Cavity types and microclimate: implications for ecological, evolutionary, and conservation studies. International Journal of Biometeorology 58:1983-1994. https://doi.org/10.1007/ s00484-014-0801-0

Amat-Valero, M., R. Václav, T. Martínez, and F. Valera. 2012. Mixed life-history strategies in a local population of the ectoparasitic fly Carnus hemapterus. Parasitology 139:1045-1053. https://doi.org/10.1017/S0031182012000534

Asghar, M., D. Hasselquist, B. Hansson, P. Zehtindjiev, H. Westerdahl, and S. Bensch. 2015. Hidden costs of infection: chronic malaria accelerates telomere degradation and senescence in wild birds. Science 347:436-438. https://doi.org/10.1126/ science. 1261121

Berthier, K., F. Leippert, L. Fumagalli, and R. Arlettaz. 2012. Massive nest-box supplementation boosts fecundity, survival and even immigration without altering mating and reproductive behaviour in a rapidly recovered bird population. PLOS ONE 7: e36028 https://doi.org/10.1371/journal.pone.0036028

BirdLife International. 2019. Coracias garrulus . The IUCN Red List of Threatened Species 2019: e.T22682860A154424974. https://dx.doi.org/10.2305/IUCN.UK.2019-3.RLTS.

T22682860A154424974.en

Błoszyk, J., D. J. Gwiazdowicz, M. Kupczyk, and Z. KsiążkiewiczParulska. 2016. Parasitic mesostigmatid mites (Acari)-common 
inhabitants of the nest boxes of starlings (Sturnus vulgaris) in a Polish urban habitat. Biologia 71:1034-1037. https://doi. org/10.1515/biolog-2016-0124

Borcard, D., F. Gillet, and P. Legendre. 2011. Spatial analysis of ecological data. Pages 227-292 in D. Borcad, F. Gillet, and P. Legendre, editors. Numerical ecology with R. Springer, New York, New York, USA. https://doi.org/10.1007/978-1-4419-7976-6_7

Borcard, D., P. Legendre, C. Avois-Jacquet, and H. Tuomisto. 2004. Dissecting the spatial structure of ecological data at multiple scales. Ecology 85:1826-1832. https://doi.org/10.1890/03-3111

Braverman, Y., R. Galun, and M. Ziv. 1974. Breeding sites of some Culicoides species (Diptera, Ceratopogonidae) in Israel. Mosquito News 34:303-308.

Bush, A. O., K. D. Lafferty, J. M. Lotz, and A. W. Shostak. 1997. Parasitology meets ecology on its own terms: Margolis et al. revisited. Journal of Parasitology 83:575-583. https://doi. org/10.2307/3284227

Calero-Torralbo, M. A., R. Václav, and F. Valera. 2013. Intraspecific variability in life-cycle synchronization of an ectoparasitic fly to its avian host. Oikos 122:274-284. https://doi. org/10.1111/j.1600-0706.2012.20374.X

Cantarero, A., J. López-Arrabé, V. Rodríguez-García, S. González-Braojos, R. Ruiz-De-Castañeda, A. J. Redondo, and J. Moreno. 2013. Factors affecting the presence and abundance of generalist ectoparasites in nests of three sympatric hole-nesting bird species. Acta Ornithologica 48:39-54. https://doi. org/10.3161/000164513X669982

Carpenter, D. S., W. Mordue, and J. M. Luntz. 2008. Selection of resting areas by emerging Culicoides impunctatus (Diptera: Ceratopogonidae) on downy birch (Betula pubescens). International Journal of Pest Management 54:39-42. https://doi. org/10.1080/09670870701469138

Černý, O., J. Votýpka, and M. Svobodová. 2011. Spatial feeding preferences of ornithophilic mosquitoes, blackflies and biting midges. Medical and Veterinary Entomology 25:104-108. https:// doi.org/10.1111/j.1365-2915.2010.00875.x

Clayton, D. H., J. A. H. Koop, C. W. Harbison, B. R. Moyer, and S. E. Bush. 2010. How birds combat ectoparasites. Open Ornithology Journal 3:41-71. https://doi.org/10.2174/1874453201003010041

Clayton, D. H., and B. A. Walther. 2001. Influence of host ecology and morphology on the diversity of Neotropical bird lice. Oikos 94:455-467. https://doi.org/10.1034/j.1600-0706.2001.940308.x

Cramp, S. 1998. The complete birds of the Western Palearctic on $C D-R O M$. Oxford University Press, Oxford, UK.

Crosskey, R. W. 1990. The natural history of blackflies. John Wiley \& Sons Ltd, New York, New York, USA.

Dautel, H., S. Scheurer, and O. Kahl. 1999. The pigeon tick (Argas reflexus): its biology, ecology, and epidemiological aspects. Zentralblatt für Bakteriologie 289:745-753. https://doi.org/10.1016/ S0934-8840(99)80049-8

Dray, S., P. Legendre, and P. R. Peres-Neto. 2006. Spatial modelling: a comprehensive framework for principal coordinate analysis of neighbour matrices (PCNM). Ecological Modelling 196:483-493. https://doi.org/10.1016/j.ecolmodel.2006.02.015

Dube, W. C., A. K. Hund, S. P. Turbek, and R. J. Safran. 2018. Microclimate and host body condition influence mite population growth in a wild bird-ectoparasite system. International Journal for Parasitology: Parasites and Wildlife 7:301-308. https://doi. org/10.1016/j.ijppaw.2018.07.007

Dupraz, M., C. Toty, E. Devillers, T. Blanchon, E. Elguero, M. Vittecoq, S. Moutailler, and K. D. McCoy. 2017. Population structure of the soft tick Ornithodoros maritimus and its associated infectious agents within a colony of its seabird host Larus michahellis. International Journal for Parasitology: Parasites and Wildlife 6:122-130. https://doi.org/10.1016/j. ijppaw.2017.05.001

Ferraguti, M., J. Martínez-de la Puente, D. Roiz, S. Ruiz, R. Soriguer, and J. Figuerola. 2016. Effects of landscape anthropization on mosquito community composition and abundance. Scientific Reports 6:29002. https://doi.org/10.1038/ srep 29002

Gameiro, J., A. M. A. Franco, T. Catry, J. M. Palmeirim, and I. Catry. 2020. Long-term persistence of conservation-reliant species: challenges and opportunities. Biological Conservation 243:108452. https://doi.org/10.1016/j.biocon.2020.108452

Gómez-Díaz, E., J. Navarro, and J. González-Solís. 2008. Ectoparasite community structure on three closely related seabird hosts: a multiscale approach combining ecological and genetic data. Ecography 31:477-489. https://doi.org/10.1111/ j.0906-7590.2008.05330.x

Goodenough, A. E., S. L. Elliot, and A. G. Hart. 2011. Do orientation-based differences in nestbox temperature cause differential ectoparasite load and explain patterns of nest-site selection and offspring condition in Great Tits? International Journal of Zoology 514913. https://doi.org/10.1155/2011/514913

Griebel, I. A., R. D. Dawson, and R. G. Clark. 2020. Cavity type influences abundance of nest-dwelling avian blow flies: an experiment with tree swallows. Ecological Entomology 45:434-443. https://doi.org/10.1111/een.12811

Griffith, D. A., and P. R. Peres-Neto. 2006. Spatial modeling in ecology: the flexibility of eigenfunction spatial analyses. Ecology 87:2603-2613. https://doi.org/10.1890/0012-9658(2006)87[2603: SMIETF]2.0.CO;2

Hamstra, T. L., and A. V. Badyaev. 2009. Comprehensive investigation of ectoparasite community and abundance across life history stages of avian host. Journal of Zoology 278:91-99. https://doi.org/10.1111/j.1469-7998.2008.00547.x

Heeb, P., M. Kölliker, and H. Richner. 2000. Bird-ectoparasite interactions, nest humidity, and ectoparasite community structure. Ecology 81:958-968. https://doi.org/10.1890/0012-9658 (2000)081[0958:beinha]2.0.co;2

Hoi, H., A. Darolová, J. Krištofik, and C. Hoi. 2018. The effect of the ectoparasite Carnus hemapterus on immune defence, condition, and health of nestling European Bee-eaters. Journal of Ornithology 159:291-302. https://doi.org/10.1007/s10336-017-1500-5 
Hoogstraal, H., and M. N. Kaiser. 1961. Ticks from EuropeanAsiatic birds migrating through Egypt into Africa. Science 133:277-278. https://doi.org/10.1126/science.133.3448.277

Kirmse, W. 2001. Reintroduction of tree-nesting peregrines (Falco peregrinus) in central Europe. Zeitschrift für Jagdwissenschaft 47:165-177. https://doi.org/10.1007/bf02241547

Klein, Á., T. Nagy, T. Csörgő, and R. Mátics. 2007. Exterior nestboxes may negatively affect Barn Owl Tyto alba survival: an ecological trap. Bird Conservation International 17:273-281. https://doi.org/10.1017/S0959270907000792

Kleindorfer, S., and R. Y. Dudaniec. 2009. Love thy neighbour? Social nesting pattern, host mass and nest size affect ectoparasite intensity in Darwin's tree finches. Behavioral Ecology and Sociobiology 63:731-739. https://doi.org/10.1007/s00265-008-0706-1

Kleindorfer, S., K. J. Peters, L. Hohl, and F. J. Sulloway. 2016. Flight behaviour of an introduced parasite affects its Galapagos Island hosts: Philornis downsi and Darwin's finches. Pages 158-179 in J. S. Weis and D. Sol, editors. Biological invasions and animal behaviour. Cambridge University Press, Cambridge, UK. https:// doi.org/10.1017/CBO9781139939492.011

Klompen, J. S. H., W. C. Black, J. E. Keirans, and J. H. Oliver, Jr. 1996. Evolution of ticks. Annual Review of Entomology 41:141-161. https://doi.org/10.1146/annurev.en.41.010196.001041

Krasnov, B. R., N. P. Korallo-Vinarskaya, M. V. Vinarski, G. I. Shenbrot, D. Mouillot, and R. Poulin. 2008. Searching for general patterns in parasite ecology: host identity versus environmental influence on gamasid mite assemblages in small mammals. Parasitology 135:229-242. https://doi.org/10.1017/S003118200700368X

Krasnov, B. R., G. I. Shenbrot, I. S. Khokhlova, M. Stanko, S. Morand, and D. Mouillot. 2015. Assembly rules of ectoparasite communities across scales: combining patterns of abiotic factors, host composition, geographic space, phylogeny and traits. Ecography 38:184-197. https://doi.org/10.1111/ecog.00915

Krasnov, B. R., G. I. Shenbrot, D. Mouillot, I. S. Khokhlova, and R. Poulin. 2005. Spatial variation in species diversity and composition of flea assemblages in small mammalian hosts: geographical distance or faunal similarity? Journal of Biogeography 32:633-644. https://doi.org/10.1111/j.1365-2699.2004.01206. $\mathrm{x}$

Lane, R. P. 1993. Sandflies (Phlebotominae). Pages 78-119 in R. P. Lane and R. W. Crosskey, editors. Medical insects and arachnids. Springer, Dordrecht, The Netherlands. https://doi.

org/10.1007/978-94-011-1554-4_4

Lareschi, M., and B. R. Krasnov. 2010. Determinants of ectoparasite assemblage structure on rodent hosts from South American marshlands: the effect of host species, locality and season. Medical and Veterinary Entomology 24:284-292. https:// doi.org/10.1111/j.1365-2915.2010.00880.x

Lázaro, R., F. S. Rodrigo, L. Gutiérrez, F. Domingo, and J. Puigdefábregas. 2001. Analysis of a 30-year rainfall record (1967-1997) in semi-arid SE Spain for implications on vegetation. Journal of Arid Environments 48:373-395. https://doi.org/10.1006/ jare.2000.0755
Legendre, P., D. Borcard, G. Blanchet, and S. Dray. 2012. MEM spatial eigenfunction and principal coordinate analyses. $R$ package PCNM, version 1-2.

Legendre, P., and L. F. J. Legendre. 2012. Numerical ecology. Elsevier, Amsterdam, The Netherlands.

Lehmann, T. 1993. Ectoparasites: direct impact on host fitness. Parasitology Today 9:8-13. https://doi.org/10.1016/0169-4758(93) 90153-7

López-Rull, I., M. Gil, and D. Gil. 2007. Spots in starling Sturnus unicolor eggs are good indicators of ectoparasite load by Carnus hemapterus (Diptera: Carnidae). Ardeola 54:131-134.

Manzoli, D. E., L. R. Antoniazzi, M. J. Saravia, L. Silvestri, D. Rorhmann, and P. M. Beldomenico. 2013. Multi-level determinants of parasitic fly infection in forest passerines. PLoS ONE 8:e67104. https://doi.org/10.1371/journal.pone.0067104

Marshall, A. G. 1981. The ecology of ectoparasitic insects. Academic, London, UK.

Martínez-de la Puente, J., J. Martínez, J. Rivero-de-Aguilar, S. Del Cerro, and S. Merino. 2013. Vector abundance determines Trypanosoma prevalence in nestling Blue Tits. Parasitology 140:1009-1015. https://doi.org/10.1017/S0031182013000371

Martínez-de la Puente, J., S. Merino, E. Lobato, J. Rivero-de Aguilar, S. Del Cerro, R. Ruiz-de-Castañeda, and J. Moreno. 2009a. Does weather affect biting fly abundance in avian nests? Journal of Avian Biology 40:653-657. https://doi.org/10.1111/ j.1600-048x.2009.04726.x

Martínez-de la Puente, J., S. Merino, G. Tomás, J. Moreno, J. Morales, E. Lobato, S. García-Fraile, and E. J. Belda. 2010. The blood parasite Haemoproteus reduces survival in a wild bird: a medication experiment. Biology Letters 6:663-665. https://doi. org/10.1098/rsbl.2010.0046

Martínez-de la Puente, J., S. Merino, G. Tomás, J. Moreno, J. Morales, E. Lobato, S. Talavera, and V. Sarto i Monteys. 2009b. Factors affecting Culicoides species composition and abundance in avian nests. Parasitology 136:1033-1041. https://doi org/10.1017/s0031182009006374

Marzal, A., F. de Lope, C. Navarro, and A. P. Møller. 2005. Malarial parasites decrease reproductive success: an experimental study in a passerine bird. Oecologia 142:541-545. https://doi. org/10.1007/s00442-004-1757-2

Merino, S., J. Moreno, J. J. Sanz, and E. Arriero. 2000. Are avian blood parasites pathogenic in the wild? A medication experiment in Blue Tits (Parus caeruleus). Proceedings of the Royal Society B: Biological Sciences 267:2507-2510. https://doi.org/10.1098/ rspb. 2000.1312

Merino, S., and J. Potti. 1996. Weather dependent effects of nest ectoparasites on their bird hosts. Ecography 19:107-113. https:// doi.org/10.1111/j.1600-0587.1996.tb00161.x

Murillo, J. M. S., J. M. C. Martín, J. L. Curdi, D. P. Pacheco, and P. M. Alarcón-Elbal. 2013. La garrapata de la paloma Argas reflexus (Fabricius, 1794)(Ixodida: Argasidae). Primera cita en Extremadura (España) e implicaciones en el ámbito de la sanidad animal y la salud pública. Revista Ibérica de Aracnología 23:103-108. 
Murray, M. D., and P. D. Kirkland. 1995. Bluetongue and Douglas virus activity in New South Wales in 1989: further evidence for long-distance dispersal of the biting midge Culicoides brevitarsis. Australian Veterinary Journal 72:56-57. https://doi. org/10.1111/j.1751-0813.1995.tb15331.x

Nartshuk, E. P., and A. V. Matyukhin. 2019. The louse flies Ornithophila metallica (Schiner, 1864) and O. gestroi (Rondani, 1878) (Diptera, Hippoboscidae): distribution and association with birds in the Palaearctic. Entomological Review 99:504-507. https:// doi.org/10.1134/S0013873819040092

Oksanen, J., F. G. Blanchet, M. Friendly, R. Kindt, P. Legendre, D. McGlinn, P. R. Minchin, R. B. O'Hara, G. L. Simpson, P. Solymos, M. H. H. Stevens, E. Szoecs, and H. Wagner. 2019. vegan: Community ecology package. $R$ package version 2.5-6. [online] URL: https://CRAN.R-project.org/package=vegan

Oorebeek, M., and S. Kleindorfer. 2008. Climate or host availability: What determines the seasonal abundance of ticks? Parasitology Research 103:871. https://doi.org/10.1007/s00436-008-1071-8

Pacejka, A. J., E. Santana, R. G. Harper, and C. F. Thompson. 1996. House Wrens Troglodytes aedon and nest-dwelling ectoparasites: mite population growth and feeding patterns. Journal of Avian Biology 27:273-278. https://doi.org/10.2307/3677258

Poulin, R. 2004. Macroecological patterns of species richness in parasite assemblages. Basic and Applied Ecology 5:423-434. https://doi.org/10.1016/j.baae.2004.08.003

Poulin, R. 2007. Evolutionary ecology of parasites. Princeton University Press, Princeton, New Jersey, USA. https://doi. org/10.1515/9781400840809

Proctor, H., and I. Owens. 2000. Mites and birds: diversity, parasitism and coevolution. Trends in Ecology and Evolution 15:358-364. https://doi.org/10.1016/S0169-5347(00)01924-8

R Core Team. 2019. R: a language and environment for statistical computing. R Foundation for Statistical Computing, Vienna, Austria. [online] URL: https://www.R-project.org/

Rodríguez, J., J. M. Avilés, and D. Parejo. 2011. The value of nestboxes in the conservation of Eurasian Rollers Coracias garrulus in southern Spain. Ibis 153:735-745. https://doi. org/10.1111/j.1474-919X.2011.01161.X

Rohlf, D. J., C. Carroll, and B. Hartl. 2014. Conservation-reliant species: toward a biology-based definition. BioScience 64:601-611. https://doi.org/10.1093/biosci/biu078

Roulin, A. 1998. Cycle de reproduction et abondance du diptère parasite Carnus hemapterus dans les nichées de chouettes effraies Tyto alba. Alauda 66:265-272.

Roy, L., A. P. G. Dowling, C. M. Chauve, I. Lesna, M. W. Sabelis, and T. Buronfosse. 2009. Molecular phylogenetic assessment of host range in five Dermanyssus species. Pages 115-142 in O. A. E. Sparagano, editor. Control of poultry mites (Dermanyssus). Springer, Dordrecht, The Netherlands. https://doi. org/10.1007/978-90-481-2731-3_12

Scott, J. M., D. D. Goble, A. M. Haines, J. A. Wiens, and M. C. Neel. 2010. Conservation-reliant species and the future of conservation. Conservation Letters 3:91-97. https://doi. org/10.1111/j.1755-263X.2010.00096.X
Sol, D., R. Jovani, and J. Torres. 2000. Geographical variation in blood parasites in feral pigeons: the role of vectors. Ecography 23:307-314. https://doi.org/10.1111/j.1600-0587.2000.tb00286.x

Sosnowski, J., and S. Chmielewski. 1996. Breeding biology of the Roller Coracias garrulus in Puszcza Pilicka Forest (Central Poland). Acta Ornithologica 31:119-131.

Sponchiado, J., G. L. Melo, T. F. Martins, F. S. Krawczak, F. C. Jacinavicius, M. B. Labruna, D. M. Barros-Battesti, and N. C. Cáceres. 2017. Ectoparasites of small-mammals: determinants of community structure in South American savannah. Parasitology 144:475-483. https://doi.org/10.1017/S0031182016001906

Stamps, J. A., and R. R. Swaisgood. 2007. Someplace like home: experience, habitat selection and conservation biology. Applied Animal Behaviour Science 102:392-409. https://doi.org/10.1016/j. applanim.2006.05.038

Tomás, G., S. Merino, J. Martínez-de la Puente, J. Moreno, J. Morales, and E. Lobato. 2008. A simple trapping method to estimate abundances of blood-sucking flying insects in avian nests. Animal Behaviour 75:723-729. https://doi.org/10.1016/j. anbehav.2007.08.018

Tsapko, N. V. 2017. Ticks (Acari, Ixodidae) of the North Caucasus: species diversity and host-parasite relationships. Entomological Review 97:542-553. https://doi.org/10.1134/ S0013873817040157

Václav, R., T. Betáková, P. Švančarová, J. Pérez-Serrano, Á. Criado-Fornelio, L. Škorvanová, and F. Valera. 2016. Nest ecology of blood parasites in the European Roller and its ectoparasitic carnid fly. Experimental Parasitology 165:71-80. https://doi.org/10.1016/j.exppara.2016.03.014

Václav, R., M. A. Calero-Torralbo, and F. Valera. 2008. Ectoparasite load is linked to ontogeny and cell-mediated immunity in an avian host system with pronounced hatching asynchrony. Biological Journal of the Linnean Society 94:463-473. https://doi.org/10.1111/j.1095-8312.2008.00985.x

Václav, R., and F. Valera. 2018. Host preference of a haematophagous avian ectoparasite: a micronutrient supplementation experiment to test an evolutionary trade-off. Biological Journal of the Linnean Society 125:171-183. https://doi.org/10.1093/ biolinnean/bly089

Václav, R., F. Valera, and T. Martínez. 2011. Social information in nest colonisation and occupancy in a long-lived, solitary breeding bird. Oecologia 165:617-627. https://doi.org/10.1007/ s00442-010-1848-1

Valera, F., H. Hoi, A. Darolová, and J. Kristofik. 2004. Size versus health as a cue for host choice: a test of the tasty chick hypothesis. Parasitology 129:59-68. https://doi.org/10.1017/S0031182004005232

Valera, F., R. Václav, M. Á. Calero-Torralbo, T. Martínez, and J. Veiga. 2019. Natural cavity restoration as an alternative to nest box supplementation. Restoration Ecology 27:220-227. https:// doi.org/10.1111/rec.12841

Valkiunas, G. 2004. Avian malaria parasites and other haemosporidia. CRC, Boca Raton, Florida, USA. https://doi. org/10.1201/9780203643792 
Valkiŭnas, G., T. Zickus, A. P. Shapoval, and T. A. Iezhova. 2006. Effect of Haemoproteus belopolskyi (Haemosporida: Haemoproteidae) on body mass of the blackcap Sylvia atricapilla. Journal of Parasitology 92:1123-1125. https://doi.org/10.1645/GE-3564RN.1

Veiga, J., P. De Oña, B. Salazar, and F. Valera. 2019a. Defining host range: host-parasite compatibility during the non-infective phase of the parasite also matters. Parasitology 146:234-240. https://doi.org/10.1017/s0031182018001233

Veiga, J., J. Martínez-de la Puente, R. Václav, J. Figuerola, and F. Valera. 2018. Culicoides paolae and C. Circumscriptus as potential vectors of avian haemosporidians in an arid ecosystem. Parasites and Vectors 11:524. https://doi.org/10.1186/s13071-018-3098-8

Veiga, J., E. Moreno, J. Benzal, and F. Valera. 2019b. Off-host longevity of the winged dispersal stage of Carnus hemapterus (Insecta: Diptera) modulated by gender, body size and food provisioning. Parasitology 146:241-245. https://doi.org/10.1017/ s0031182018001300

Veiga, J., R. Václav, and F. Valera. 2020. The effect of parasite density on host colonization success by a mobile avian ectoparasite. Ecological Entomology 45:867-875. https://doi. org/10.1111/een.12864

Veiga, J., and F. Valera. 2020. Aridez y ectoparásitos aviares: ¿quiénes, cuántos y dónde? Ecosistemas 29:1986. https://doi. org/10.7818/ecos. 1986

Venables, W. N., and B. D. Ripley. 2002. Modern applied statistics with $S$. Fourth edition. Springer, New York, New York, USA. https://doi.org/10.1007/978-0-387-21706-2

Wegner, P., G. Kleinstäuber, F. Baum, and F. Schilling. 2005. Long-term investigation of the degree of exposure of German Peregrine Falcons (Falco peregrinus) to damaging chemicals from the environment. Journal of Ornithology 146:34-54. https://doi. org/10.1007/s10336-004-0053-6

White, C. M., N. J. Clum, T. J. Cade, and W. G. Hunt. 2002. Peregrine Falcon (Falco peregrinus). In A. Poole editor. The birds of North America. Cornell Lab of Ornithology, Ithaca, New York, USA. https://doi.org/10.2173/bow.perfal.01 
Nest-box location determines the exposure of the host to ectoparasites

\section{Appendix A1}

\section{Additional tables}

Table A1.1. Results of CCA analyses on the occurrence of ectoparasites of the European roller at the infracommunity level during the three study years.

\begin{tabular}{cccccccccc}
\hline \hline & \multicolumn{3}{c}{2016} & & \multicolumn{3}{c}{2017} & \multicolumn{3}{c}{2018} \\
& Inertia & Proportion & Rank & Inertia & Proportion & Rank & Inertia & Proportion & Rank \\
\hline Total & 1.42 & 1.00 & & 1.80 & 1.00 & & 1.39 & 1.00 & \\
Constrained & 0.40 & 0.28 & 2 & 0.43 & 0.24 & 3 & 0.36 & 0.26 & 2 \\
Unconstrained & 1.03 & 0.72 & 6 & 1.37 & 0.76 & 6 & 1.03 & 0.74 & 6 \\
\hline
\end{tabular}

Permutation tests for CCAs under reduced models.

\begin{tabular}{ccccccccccccc}
\hline \hline & \multicolumn{4}{c}{2016} & \multicolumn{1}{c}{2017} & \multicolumn{4}{c}{2018} \\
& df & $\chi^{2}$ & $F$ & $\operatorname{Pr}(>\mathrm{F})$ & df & $\chi^{2}$ & $\mathrm{~F}$ & $\operatorname{Pr}(>\mathrm{F})$ & df & $\chi^{2}$ & $\mathrm{~F}$ & $\operatorname{Pr}(>\mathrm{F})$ \\
\hline CCA1 & 1 & 0.30 & 7.82 & 0.001 & 1 & 0.30 & 7.02 & 0.001 & 1 & 0.30 & 9.77 & 0.001 \\
CCA2 & 1 & 0.10 & 2.62 & 0.020 & 1 & 0.10 & 2.27 & 0.126 & 1 & 0.05 & 1.64 & 0.151 \\
CCA3 & - & - & - & - & 1 & 0.03 & 0.76 & 0.624 & - & - & - & - \\
Residual & 27 & 1.03 & & & 32 & 1.37 & & & 33 & 1.03 & & \\
\hline
\end{tabular}


Table A1.2. Results of RDA analyses on the abundance of ectoparasites of the European roller at the infracommunity level during the three study years.

\begin{tabular}{cccccccccc}
\hline \hline & \multicolumn{3}{c}{2016} & & \multicolumn{3}{c}{2017} & \multicolumn{3}{c}{2018} \\
& Inertia & Proportion & Rank & Inertia & Proportion & Rank & Inertia & Proportion & Rank \\
\hline Total & 0.22 & 1.00 & & 0.20 & 1.00 & & 0.20 & 1.00 & \\
Constrained & 0.08 & 0.36 & 3 & 0.05 & 0.23 & 3 & 0.06 & 0.29 & 3 \\
Unconstrained & 0.14 & 0.64 & 4 & 0.16 & 0.77 & 4 & 0.15 & 0.71 & 4 \\
\hline
\end{tabular}

Permutation tests for RDAs under reduced models.

\begin{tabular}{ccccccccccccc}
\hline \hline & \multicolumn{4}{c}{2016} & \multicolumn{4}{c}{2017} & \multicolumn{4}{c}{2018} \\
& df & Variance & $\mathrm{F}$ & $\operatorname{Pr}(>\mathrm{F})$ & df & Variance & $\mathrm{F}$ & $\operatorname{Pr}(>\mathrm{F})$ & df & Variance & $\mathrm{F}$ & $\operatorname{Pr}(>\mathrm{F})$ \\
\hline RDA1 & 1 & 0.06 & 10.03 & 0.001 & 1 & 0.03 & 5.26 & 0.006 & 1 & 0.05 & 10.26 & 0.001 \\
RDA2 & 1 & 0.02 & 3.77 & 0.027 & 1 & 0.02 & 3.20 & 0.036 & 1 & 0.01 & 2.70 & 0.090 \\
RDA3 & 1 & $<0.01$ & 0.16 & 0.952 & 1 & 0.01 & 1.15 & 0.327 & 1 & $<0.01$ & 0.08 & 0.989 \\
Residual & 25 & 0.14 & & & 32 & 0.15 & & & 32 & 0.15 & & \\
\hline
\end{tabular}

